\title{
Viewpoint: Empowering diversity: Envisioning, designing, and developing range management science
}

\author{
DAVID L. SCARNECCHIA
}

Author is Associate Professor, Department of Natural Resource Sciences, Washington State University, Pullman, Wash., and Book Review Editor, Journal of Range Management.

\begin{abstract}
The fragmented, weak identity of range science has been disadvantageous to the institutions and individuals involved with it. This paper addresses a complex, interrelated group of issues related to range science, the Journal of Range Management, and the Society for Range Management. Beginning with the longstanding conception of the art of range management, it presents a concept of range management science that has multiple implications for the Society for Range Management and its flagship publication, the Journal of Range Management. The paper presents a strategically designed identity for range management science as a synthetic science, i.e., a science of synthesis, and examines the elements of diversity, synthesis, and communication that are the essence of that identity. It encourages a diverse, inclusive, synergistic character for, and offers many suggestions related to the philosophy and conduct of, the science, the Journal, and the Society. The harmonious vision of range management science that it presents is designed to give the science a strong, coherent, marketable identity. The vision is dynamic in that it can readily accommodate evolving changes. That vision is designed to make the diversity of the science and the Society work for us, rather than against us, by establishing a philosophical environment where the kind of scientific, institutional, informational, and professional synergies we need can flourish.
\end{abstract}

Key Words: synthesis, concepts, diversity, Journal of Range . Management, Rangelands, university range programs, art

This paper addresses a complex, interrelated group of issues related to range science and the Society for Range Management. The paper's mission is explanation of a vision of range management science-a comprehensive vision directed at achieving multiple objectives for the science, for the Society, and for the educational and research institutions involved with them. It presents a concept of range management science as an inclusive, integrative, synthetic management science of diverse kinds of communication.

The analyses in the paper are conducted from a perspective formulated from the following evaluations:

1. The current trend toward diversity and inclusiveness in range science, and in the membership of the Society for Range

\footnotetext{
The author would like to thank Drs. M. M. Kothmann and J. K. Dobrowolski for their reviews of the manuscript.

Manuscript accepted 15 Jul. 2003.
}

Resumen

Las diversas instituciones asociadas con la ciencia de pastizales han sufrido de la fragmentación de la ciencia e identidad débil. Este artículo aborda un grupo interrelacionado y complejo de problemas relacionados a la ciencia de pastizales, el Journal de Manejo de Pastizales y la Sociedad para el Manejo de Pastizales. Iniciando con la concepción largamente sostenida del arte de manejo de pastizales se presenta un concepto de ciencia de manejo de pastizales que tiene múltiples implicaciones para la Sociedad para el Manejo de Pastizales y su principal publicación, el Journal de Manejo de Pastizales. El articulo presenta una identidad estratégicamente diseñada para la ciencia de manejo de pastizales como una ciencia sintética, esto es, una ciencia de síntesis, y examina los elementos de diversidad, síntesis y comunicación que son la esencia de tal identidad. Motiva a un carácter diverso, incluyente y sinérgico y ofrece muchas sugerencias relacionadas con la filosofía y conducta de la ciencia, el Journal y la Sociedad. La visión harmoniosa de la ciencia de manejo de pastizales que el presenta esta diseñada para dar a la ciencia una identidad fuerte, coherente y vendible. La visión es dinámica de tal manera que puede fácilmente acomodar los cambios de se desarrollan. Esa visión esta diseñada para hacer que la diversidad de la ciencia y de la Sociedad trabaje para nosotros y no en contra de nosotros mediante el establecimiento de un ambiente filosófico en donde pueda florecer el tipo de sinergia científica, informacional y profesional que nosotros necesitamos.

Management, have arisen naturally, i.e., ecologically, in a competitive environment, and so may be used as indicators of the natural trend in the identity of range science.

2. Diversity and inclusiveness in range science and the Society for Range Management are strengths to be fostered and utilized, not weaknesses to be diminished or circumvented.

3. The Society for Range Management currently faces significant problems, including declining membership, questions about the quality of its underlying science, and a fragmented professional vision, and these problems are not the result of a single circumstance, but are the result of an interrelated complex of circumstances.

4. These problems are better addressed by execution of a comprehensive plan that will involve professional synergies to achieve multiple objectives, and by a plan that is dynamic, i.e., that can readily accommodate inevitable future change. 
5. To be successful, any such plan will effectively use the natural diversities of the science and profession to work for the science and the Society by philosophically unifying them, rather than allow those diversities to work against the science and the Society by philosophically fragmenting them.

6. The principal function of the Society for Range Management is communication, not advocacy.

7. The character and identity of range science have been inadequately defined by the Society, and this inadequate definition has contributed to the Society's current limitations.

The paper begins with an analysis of past and present interpretations of the art and science of range management, and a notable early concept of range science. It then addresses the visualization of range management science. It examines the importance of communication and art, and the mutual importance of identity and communication to each other in range management science. The paper examines the implications of range management science for the name of the Society for Range Management. It makes specific recommendations regarding the Society's flagship publication, the Journal of Range Management, and evaluates the general implications of range management science for the Society's popular publication, Rangelands. It explores diverse implications of an inclusive concept of range management science for programs at the land-grant universities. The international dimensions of range management science are examined. The paper returns to another aspect of communication with a discussion of the challenge facing the next incarnation of the committee to revise the Glossary of Terms Used in Range Management.

Throughout its development, the paper emphasizes the importance of a broad concept of synthesis in range management science, expanding or generalizing elements of synthesis that are discussed or exemplified in 4 other papers (Scarnecchia 2004a, 2004b, 2004c, 2004d). Along the way, the paper makes many suggestions, but adoption of a diverse, inclusive, integrative concept of range management science is explicit or implicit in all of them.

\section{Range Science and Range Management}

The problem of identification of range science can be traced back to historically frequent and sometimes lengthy philosophical discussions about the distinctions between art and science, and between range science and range management. The question of the relationship between range science and range management has been considered many times in published work (e.g., Provenza 1991), at professional meetings, and in classrooms. I am unsure about the published origin of the term range science, but among the most conspicuous early uses of the term is that in the third edition of Range Management (Stoddart et al. 1975). The term was absent from the second edition (Stoddart and Smith 1955). Range science was not explicitly defined in the third edition, but was defined graphically in Figure 1, which is reproduced here.

Examining Figure 1, range science was represented as a central science that drew on a number of other specialized sciences, including ecology, soils, sociology, etc. Each of these specialized sciences contributed to range science, contributing to the band inside of these basic sciences (Fig. 1), i.e., to the outside band of what was represented as range science. The band itself, presumably, consisted of specialized sub-sciences within range science, e.g., range ecology, range economics, range wildlife biology, etc. Whatever its origin, and whatever the intentions of its designer, Figure 1 begs an obvious question; what is in the (curiously large) core of range science?

You will not find much in the published literature that attempts to answer this question, other than several papers from the middle and late 1990's (e.g., Scarnecchia, 1995a, 1996, 1999). In fact, 25 years after the publication of Figure 1, the most widely used current textbook in range management (Holechek et al. 2004) has only a single brief paragraph of 6 sentences on range science, and following the definition of Provenza (1991), defines it as "the organized body of knowledge upon which range management is based." Figure 2, taken from that book, clearly does not answer the foregoing question about the identity of range science. In fact, examining Figure 2, range science is not even in the figure. Where is it? Why does it not have the standing of the other sciences shown in Figure 2? And why is a whole generation of university students taking courses in range management without being given a clear vision, beyond 6 sentences, of what range science is? Twenty-five years later, in the roll call of sciences in Figure 2, range science has, with more than a touch of paradox and irony, turned up missing.

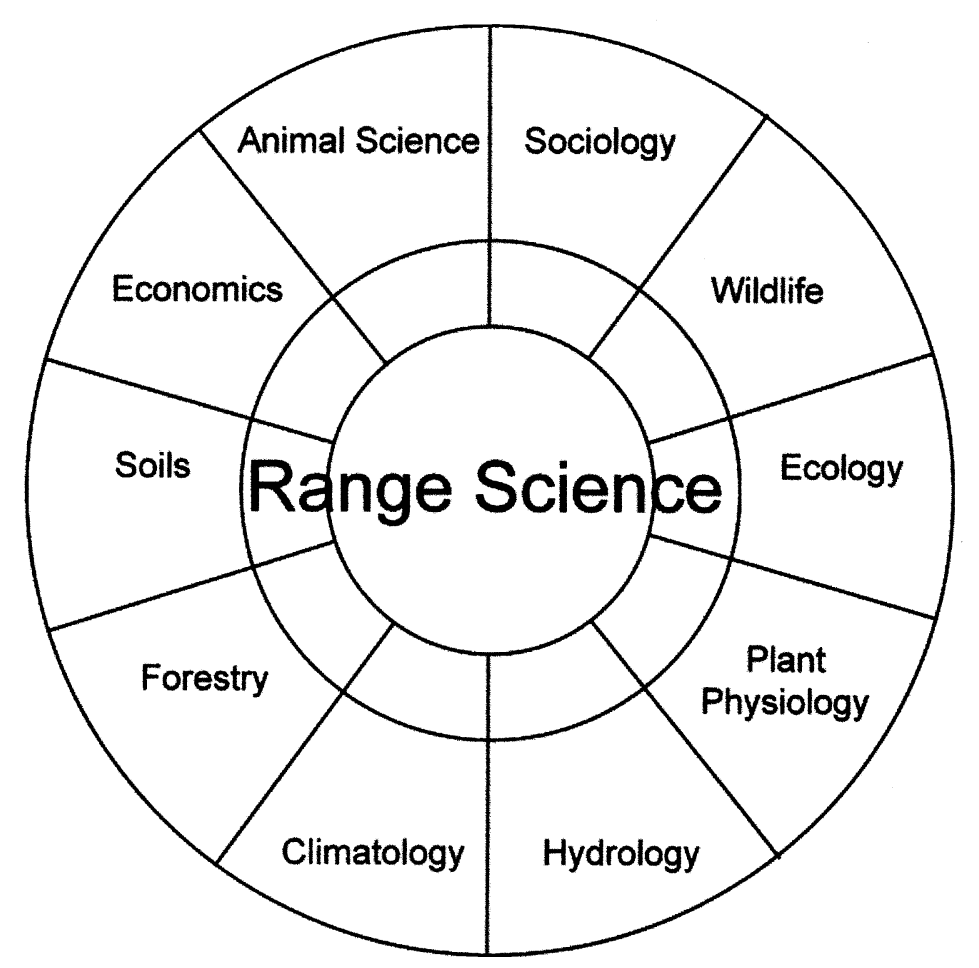

Fig. 1. Range science as conceived in the major textbook on range management in 1975 (Stoddart et al. 1975). Neither the figure nor the book's text suggests the nature of the central core, or the band surrounding the core, although both are considered within range science. (Reprinted by permission of The McGraw-Hill Companies, Two Penn Plaza, New York, N.Y.) 


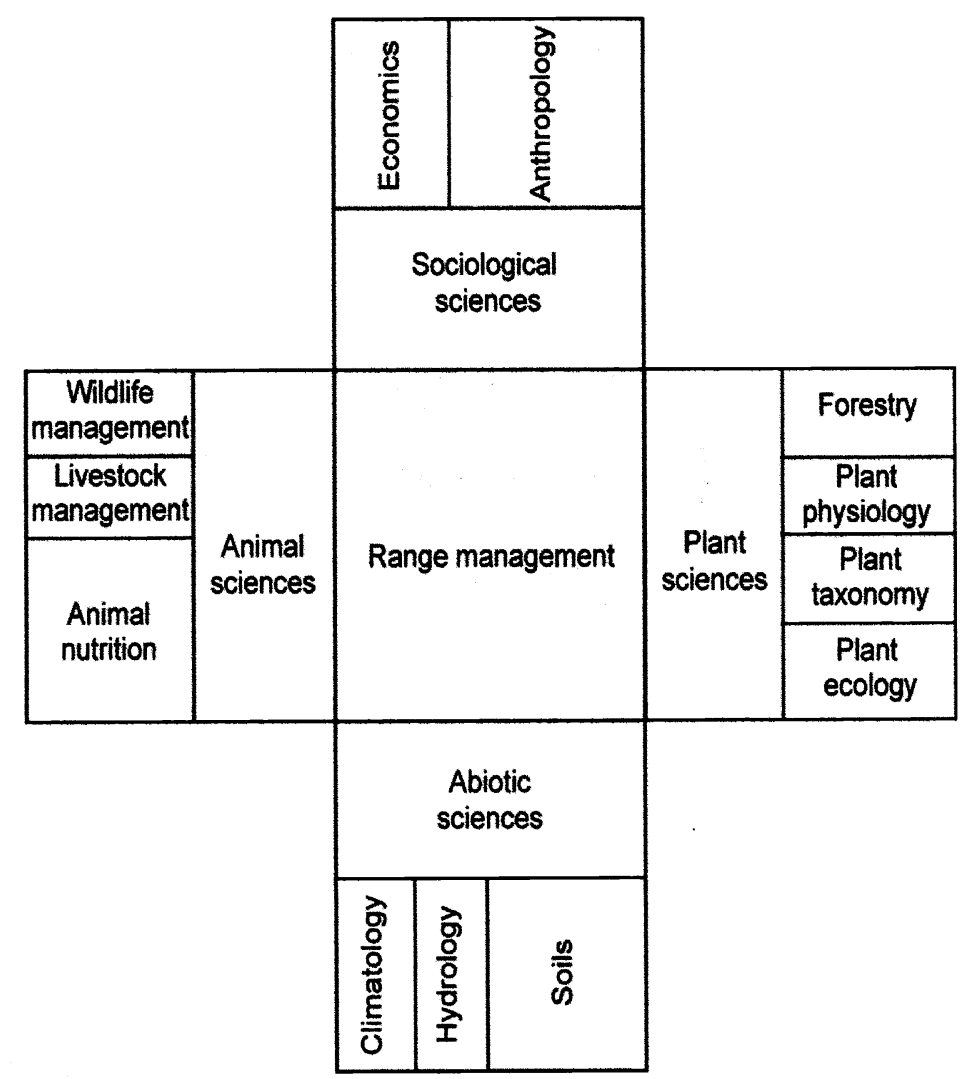

Fig. 2. Range management as envisioned in the major textbook on range management in 2004 (Holechek et al. 2004). Range science's absence in noteworthy, as is its minimal description in the book's text. (Reprinted or electronically reproduced by permission of Pearson Education, Inc., Upper Saddle River, N.J.)

\section{An Identity for Range Science - Choosing Strategically}

Notwithstanding the 3 papers related to range science cited above, the absence of range science in Figure 2 implies convincingly that the science has not developed a strong individual identity. The problem is not limited to range management textbooks. The several incarnations of the committee to work on the Glossary of Terms Used in Range Management, have, in my view, given insufficient emphasis to terminology describing what range science is. If a science, a discipline, or their working professionals cannot be concisely identified, they have identity problems.

Some see the core of range science as being, for example, range ecology. If the designer of Figure 1 had envisioned one of the disciplinary sciences, e.g., range ecology, as the core of range science, Figure 1 would have been drawn like Figure 3 . Although ecological systems, and the concepts of ecological science have great importance in range science, the science of ecology, and its sub-sciences (e.g., terrestrial ecology, arid land ecology, aquatic ecology, riparian ecology) have long- established identities and institutions that leave little room for range ecology as a strong core for range science. Despite the long history of contributions of ecology to range science, the science has yet to find a distinct identity in, or as, range ecology. And as noted in earlier writing (Scarnecchia 1995b), even though most know that the Greek root of ecology, oikos, means home, range science is unlikely to find a comfortable professional home there.

The failure to develop a distinct identity for range science has contributed significantly to the recent and ongoing political and financial misfortunes of range management. As a starting point to improve our fortunes-for the academic institutions involved with range science, for the identities of the Journal of Range Management and Rangelands, and for expanded future success of the Society for Range Management-we need to establish a viable, functional identity for range science.

\section{Management Science and Range Management Science}

The term management science is used here in a broad sense to mean an integrated science of concepts, experimental research, and analytical approaches designed, organized and oriented at management. Important earlier works describ-

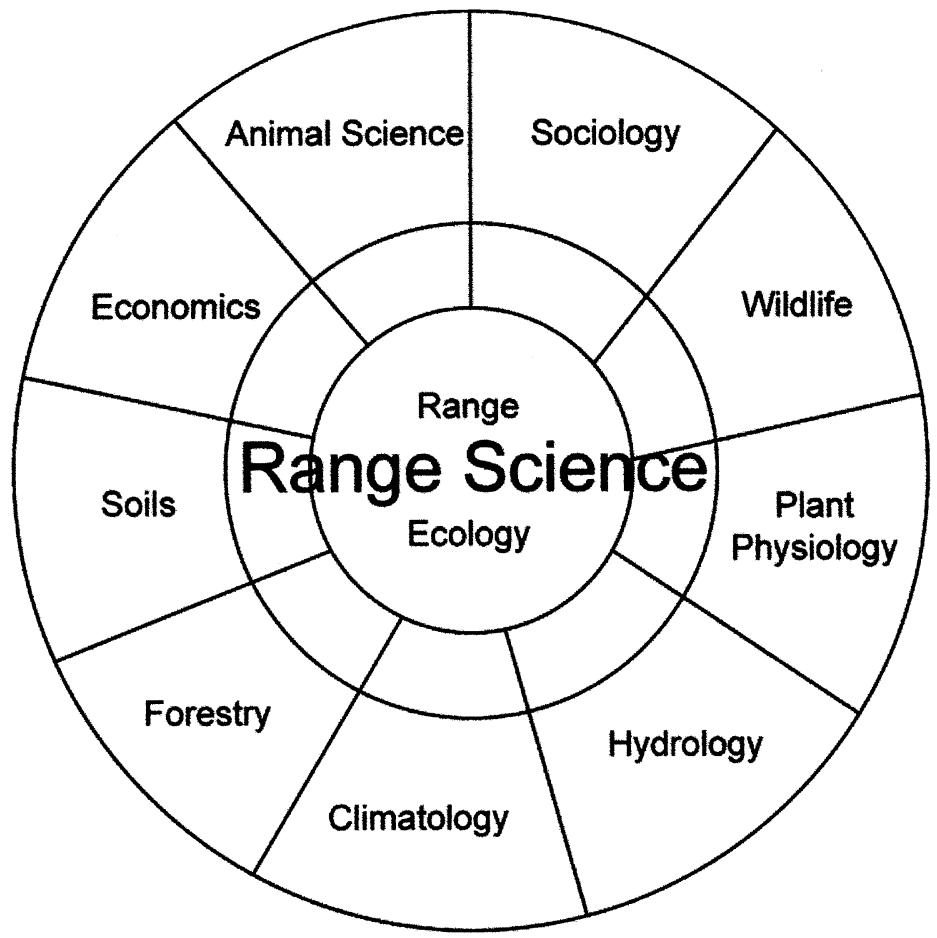

Fig. 3. Range science as represented in Figure 1, with range ecology at the core. As a technical, specialized sub-science, range ecology makes a poor center or core for range science. 
ing management science (e.g., Forrester 1961) and more recent ones (e.g., Gass and Harris 1996) have not always concisely or explicitly defined management science, but historically the term has often been tied to the more narrowly conceived operations research, and to a complex of analytical (modeling) techniques directed at optimization problems. Specialized scientists may tend to view the concepts above, including management science, narrowly, but virtually all problems in science and management involve optimization.

Management science has been successfully established as an analytical science, and some modeling tools have been applied to problems of rangelands or range management. But management science elements, including concepts, tools and terminology have seldom or only slowly been effectively integrated into mainstream range science. The more technically developed sciences of wildlife biology, animal sciences, and forestry have likewise been notably ineffective in integrating elements of management science into their scientific cores, but their longer histories, their associations with higher-value products, and their better-established constituencies have allowed them to maintain their scientific integrities and identities more successfully than has range science (Scarnecchia 1995a).

Figure 1 is a useful place to start in defining range science not as a specialized basic science, but as an inclusive, integrative management science, i.e., as range management science. The essential features of Figure 1 were accentuated in Figure 4, reproduced from Scarnecchia (1995a), and are further refined in Figure 5. As a model, range science becomes a management science that includes a mantle consisting of elements of other sciences that contribute to it (Fig. 5). The mantle area of Figure 5 represents where most of the research that has been done by individuals who define themselves as range ecologists, range hydrologists, range plant physiologists, range animal nutritionists, etc., is located. Some of the research in the mantle has historically been theoretical, involving, for example, ecological theories, but most has been experimental, involving data.

Interestingly, if we consider a range management science as represented in Figure 5, the problems of identification disappear. The representation of range management science in Figure 5 is patterned after Earth, but unlike Earth, whose core is mostly highly tangible iron, the core of range management science is an

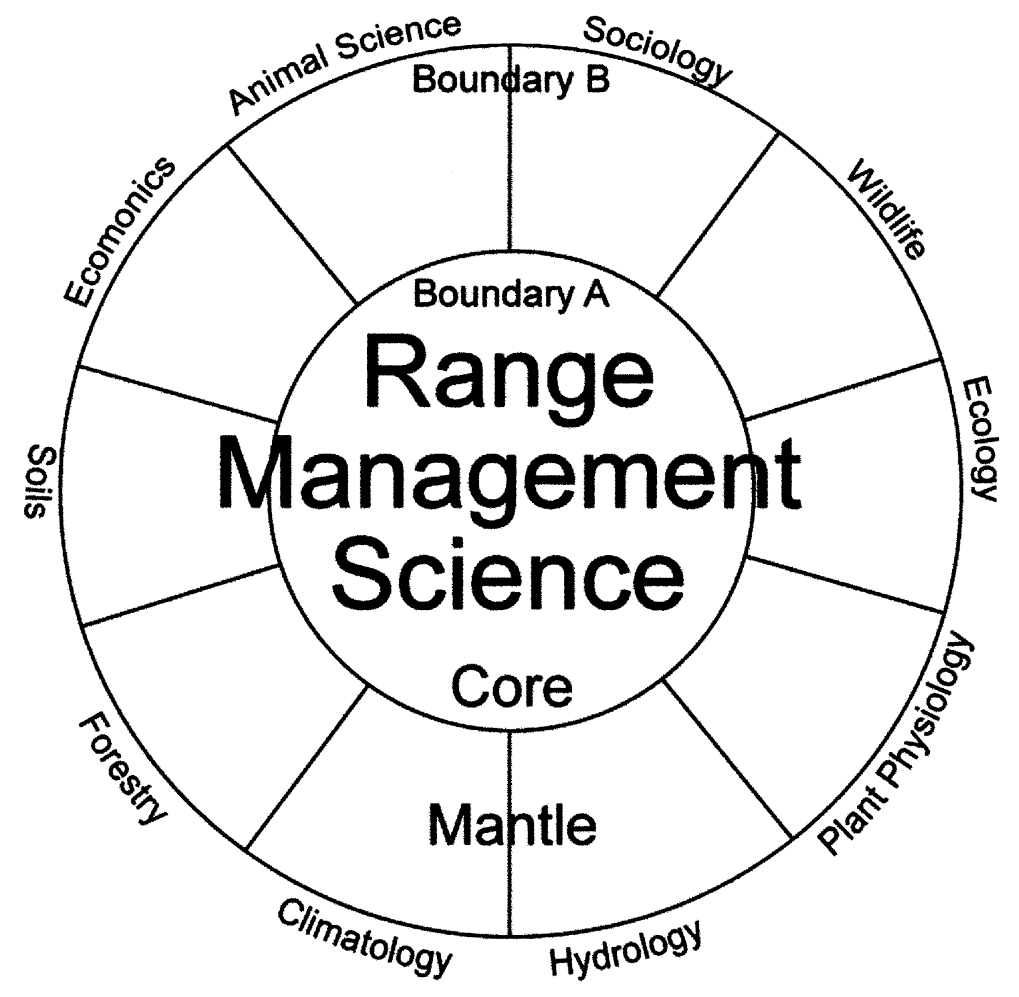

Fig. 4. Range science as range management science, as adapted from an earlier paper by Scarnecchia (1995a). The core of range management science was envisioned to consist of diverse, designed, abstract concepts, from simple basic variables to complex integrative concepts like rangeland condition or health.

amorphous, undifferentiated mass. Actually, to think of it originally having been, and still largely as, a kind of primordial, (albeit conceptual) unsynthesized ooze analogous to that described by Loren Eiseley in The Immense Journey (1959) is metaphorically accurate, and immensely useful. Just as higher forms of life arose from primordial ooze through some manner of evolutionary synthesis, the primordial core of range management science must be synthesized into a management science of useful concepts-concepts abstracted to varying degrees and useful in communication of many kinds. At its core, range management science is a synthetic science-a product of synthesis.

\section{Synthesis, Art, and Range \\ Management Science}

Such an abstract, conceptual vision of range management science as a science of synthesis is not incompatible with the reality of rangeland. In his book Synergetics, Buckminster Fuller (1975) wrote: The artist was right all the time; nature is conceptual. That statement has philosophical merit, because our concept of nature is, by definition, conceptual. But pragmatically, to consider range management science as a model, as designed, as manmade, as conceptual, is extraordinarily useful. The design of tools to investigate, analyze, explain and communicate is the synthesis that defines a unique science, and the diverse manifestations of that synthesis will give range management science a distinct identity.

For that reason, art and design are included as important contributors to range management science (Fig. 5). The segments representing the basic sciences are of differing widths, representing the idea that some sciences, such as ecology, contribute more content to range management science, and others may have potential to contribute more. The relative widths of these slices change over time as the relative influences of these contributing sciences change. The 3 sets of dotted slices in that figure are left mostly unnamed in anticipation that still other sciences or branch sciences may contribute to the development of range management science in ways that are currently unrecognized or unanticipated. As an inclusive, integrative management science, range management science should be open and receptive to these creative contributions 


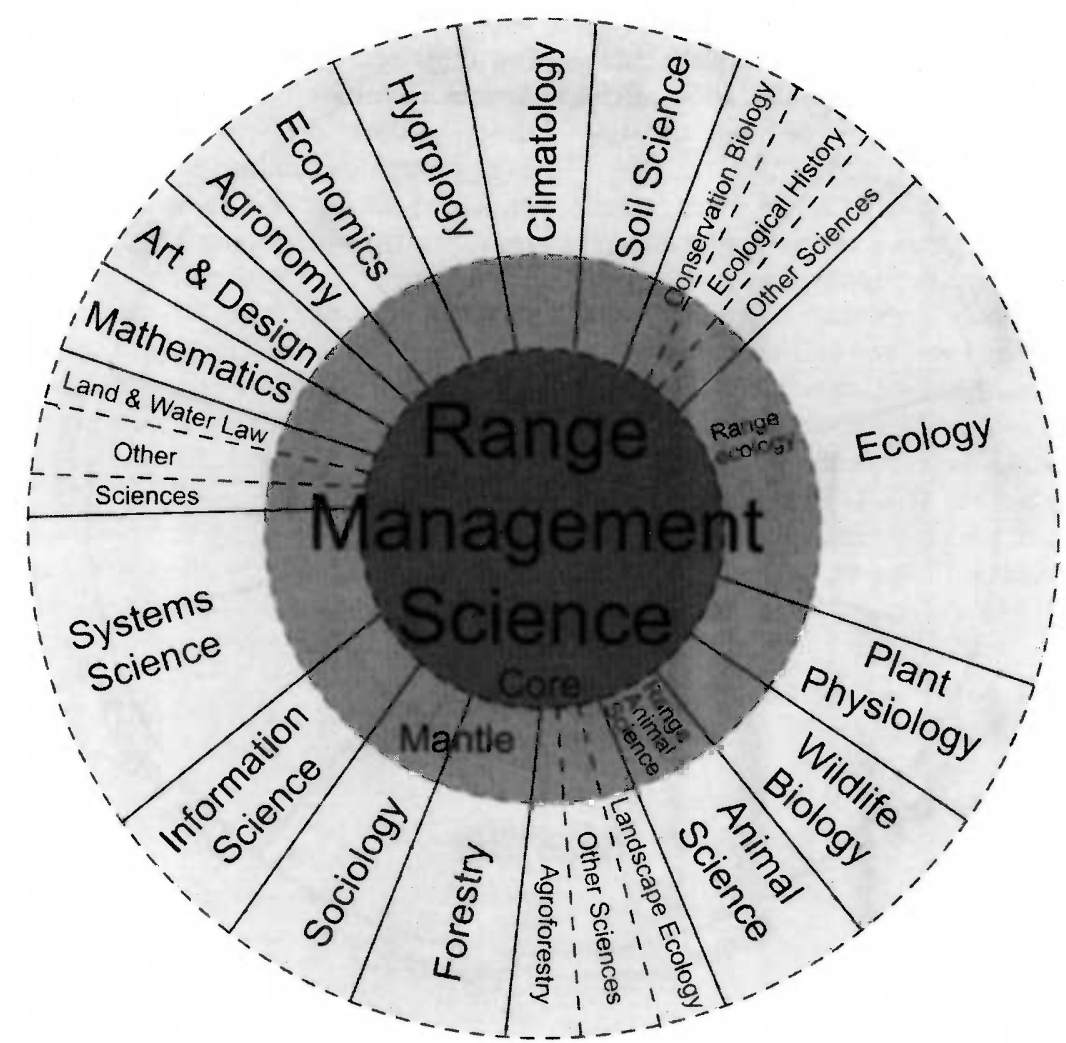

Fig. 5. Range management science as the diverse, integrative management science envisioned in this paper. The figure is dynamic in several senses. Information can flow inward from the specialized sciences to range management science, or outward from range management sciences to the specialized sciences. The relative importance of contributions of the various specialized sciences to range management science will change over time. Also, individual identities of the sciences and sub-sciences can change. Both the figure, and the management science it represents, are designed to accommodate these dynamics.

from other developing basic or applied sciences.

Although less tangible, the identity of range management science as the integrative management science represented in Figure 5 is a more powerful identity than any identity tied to a particular specialized science like ecology, or an identity tied simply to rangeland. As a latter-day science, range science has been notably ineffective in establishing a viable identity partly because specialized sciences from ecology to forestry to wildlife biology to agricultural economics to rural sociology have usurped the specialized identities, ecosystem components, and valuable products by prior claim. In simple terms, if we concede the wildlife to the wildlife biologists, the water to the hydrologists, the trees to the foresters, the plant communities to the plant ecologists, the domestic livestock to the animal scientists, the people and their communities to the rural sociologists, etc., range scientists have little to investigate, and range managers little to manage. Conspicuously few high-value products or specialized processes of ecosystems remain.
But the potential to synthesize-to design concepts, develop interactive approaches, pursue multiple efficiencies, and package information to communicate among the more specialized sciences is enormous. As an interactive, integrative, management science of synthesis, and of communication of many kinds, range management science is not crowded into a specialized competitive niche of low-value products or specialized processes, but instead has all of the scientific space of the open range.

The idea of range science as a management science is not without historical origins. For example, definitions of rangeland have usually been based on the kind of management applied to land rather than to specific, physical characteristics of the land. Furthermore, the idea that the essence of range management science is a synthetic science-a science of synthesis-should not seem radical. Philosophically, it is a formalization of the long established (e.g., Stoddart and Smith 1943) concept of range management as an integrative art. Some of our more complex concepts in range management science, including range condition, range health, carrying capacity and range readiness have widely recognized, implicit images in the history of what has frequently been termed the art of range management, even if their explicit identities in range science have developed only grudgingly. Such art has long been considered a significant part of range management, even if art was sometimes interpreted vaguely, only as a kind of integrated judgment that transcended limitations in quantifiable science.

But art was not explicitly present in the early conceptions of range science (see Fig. 1), and art is not commonly considered a significant component of any of the specialized sciences contributing to range science in Figure 1. Somehow we have not pursued the observations of Forrester (1961) that as the science grows, it allows further extension of the art. Ironically, had we, over the past 50 years, pursued the technical essence of the art of range management with the analytical fervor that we have pursued the science, range management science would have been better identified and further advanced than it is today. In any case, a management science philosophy does not dispense with art; it includes art; it welcomes art; and it fosters art by providing an environment in which we can pursue creative synthesis.

This paper does not suggest that we reduce our interest in experimental research or experimental science. It does suggest that we increase our attention to synthesis, that we recognize diverse analytical research, including modeling research, as essential research within range management science, and that we correctly visualize the role of experimental science within the broader structure in an integrative range management science.

\section{A Science of Communication}

To accomplish synthesis, organization is essential, as is communication. In fact, whether defining a basic concept like an animal-unit (Scarnecchia and Gaskins 1987), applying an ecological theory in assessing range health, explaining a scientific principle to a manager, or solving a multi-variable problem involving multiple human objectives or multiple efficiencies, in its functional synthetic core, range management science is almost entirely a science of communication. Much more than being simply applied ecology, land management or people management, it is a management science that should be designed to investigate, analyze, integrate, 
and communicate multiple objectives, variables, interactions, values, and behaviors of complex systems, that involve, broadly, rangeland. The land that it is directed at managing is real and natural. But the synthetic core of range management science is abstract, conceptual, and man-made.

An example of a problem in range management science is that of assessing rangeland health, a more comprehensive, multiple-objective conceptual expansion of assessment models that have historically been termed rangeland condition and rangeland trend. Much of the attention directed at this problem in recent years has focused on what ecological model of plant community succession is superior, e.g., traditional Clementsian succession or a state-transition model. Conceptually, this argument about ecological models is within the mantle of range management science (Fig. 2); the argument over the general validity or at hoc appropriateness of ecological theories or ecological models, important though it may be, is clearly central to ecology.

The challenge within the core of range management science is to develop a generalized model of values, concepts, variables and sampling protocols to apply appropriate models in appropriate locations on appropriate and diverse scales. Any model that does these things involves much more than just rangeland; it involves, among other elements, other specialized sciences (Fig 5), human values, several kinds of communication, and skillful, organized, integrated design. In that sense, the term rangeland health is too narrow to fully describe the diverse elements involved. In any case, when an individual or committee attempts to develop such a model of rangeland health, consideration of the relative validities of different ecological models is a relatively small part of the process.

Ideally, a general rangeland health model should be designed with a modular structure so that submodels, such as particular models of ecological succession, could be applied selectively where appropriate, by a generalized model of rangeland health (Scarnecchia 1995a). Whether universal or local in application, a rangeland health model should be designed to apply, interpret, translate, and in at least those 3 senses, communicate information about the health of rangeland to individuals concerned with management. The ecological models are models central to ecology, but the rangeland health model, with multiple objectives, multiple values, and indicator variables, compares ecological conditions with an ecological model on appropriate spatial and temporal scales, and is essentially a communication model within the core (Fig. 5) of range management science.

The visualization of range management science as a science of communication is timely in an age when accurate, useful information is becoming a more valuable product than ever, and information science, or informatics is flourishing. Much of modern informatics is concerned with the function of communicating valid information in a form that is useful for making decisions, and the variables, interactions, and models of that function are part of the core of range management science.

\section{Another Kind of Communication}

What we have here is a failure to communicate...

-- From the Film Cool Hand Luke.

If you think range management and range science do not have identity problems at the academic level, you are not listening to the hesitant words of your colleagues or mentors when they are asked what they do for a living.

Ask around. By that I mean, the next time you are sitting at a table of scientists in the ecological, natural resource, or agricultural sciences, ask them to give their name and to identify their discipline. Agricultural economists will say they are agricultural economists. Wildlife biologists will say that they are wildlife biologists. Plant ecologists will tell you they are plant ecologists.

Most professionals associated with range management science will, in my experience, start squirming. Few seem comfortable calling themselves range scientists, maybe because many do not see themselves as real scientists in the sense of a chemist, an ecologist, an experimental physicist, or other specialized scientist.

They will answer in one of several ways. The fortunate few who have strong scientific ties to one of the specialized sciences supporting range management science will answer with the likes of: I' $m a$ range ecologist, range hydrologist, range animal nutritionist, etc. All of these specialties are, according to Figure 5, in the mantle of range management science.

The less fortunate others who are more generalist in their expertise will answer in 1 of 2 ways. Some will say, usually with some discomfort, that they are in range management, but this answer is unsatisfying for 2 reasons. First, most probably realize that they do not work in actual management, but instead work mostly with concepts and data. They are managing their research programs, not range. That reason may be why few would ever describe themselves as range managers, even though they admit to being in range management. Second, most academics are less comfortable being identified with management than with science anyway; at tables in meetings at universities, in academia generally, managers do not have the credibility that scientists do. In academia, professional peers do not always recognize people in management disciplines as real scientists.

Disciplinary discomfort with the word management leads to the third kind of response to the question of discipline. People will sometimes answer that they are in range, or are a range person, or a range type. I am sure you have heard individuals describe themselves or others in these terms. These vacuous, vague references, besides being symptomatic of the individual's lack of identity, erode the identity of range management science. Such references are more insidious than harmless; they perpetuate professional anonymity, even as they conjure narrow, exclusionary imagery of what, for example, a range type is.

In a recent Trail Boss News article, Vavra (2003) described the inadequate definition of "range management," expressed concern over the narrowness of "a considerable number" of peoples' definitions of range management, noted the virtual absence of Forest Service personnel who are classified as "range scientists," but concluded that "what we call ourselves (wildlife biologist, hydrologist, animal nutritionist, habitat biologist) is unimportant; the important thing is SRM provides a common forum for people interested in managing natural resources. I think we are unique in being a truly multidisciplinary society. We need to market that reality concept."

While he states (Vavra 2003) that he "never took a course in marketing," I expect that he would acknowledge the measurably greater difficulty in effectively marketing a discipline, a Society, a scientific journal, and their individual professionals without concise, coherent nomenclature to market. Clearly, we will benefit from precise, coherent nomenclature to describe a discipline, a Society, a journal, and the professionals involved with them.

One of the advantages of adopting the concept of an integrative range management science as described here is that professionals involved with range management science can be easily named. 
Referring to Figure 5, scientists who consider themselves range ecologists, range hydrologists, range economists, etc. can retain these identities and still be range management scientists within the mantle of Figure 5. Some of these individuals who do not want to be known as specialists, and other scientists working in integrative or generalist aspects of range management science, can find identity in the core, and can refer to themselves as simply range management scientists.

The other professionals that contribute to range management science are technical personnel, sometimes referred to as technical specialists (Fuhlendorf et al. 1999). They apply range management science in their work. But historically, due to the poor development of range management science, and the complexity of problems in range management, few of these people have been involved strictly with the implementation of active management. At some time, most of them design concepts, conduct analyses, create ad hoc approaches or protocols, or develop other creative, synthetic tools that may contribute to range management science. Coordinated Resource Management is one of many examples of such approaches. Even cursory examination of the program at the recent meeting of the Society for Range Management in Casper, Wyo. clearly shows the enormous diversity and depth of ongoing and potential contributions of these technical professionals to range management science.

But because range management science as described here is not specialized in the traditional (narrow, and sometimes grazing) sense, the term range management specialist is sub-optimally descriptive. The term range management technician better describes the role that these professionals have in designing, modifying, and applying the technical information of range management science.

The Society for Range Management has shown little leadership in assigning, and little discipline in applying, appropriate titles to its professionals. Instead, universities, the USDA-ARS, and agencies like the Natural Resource Conservation Service, Forest Service, and Bureau of Land Management have filled this role and provided names, often derived from titles of position descriptions within their bureaucracies. The result has been not only fragmentation in the names used, but also the appearance and persistence of names like range conservationist. Not only are such titles not especially descriptive, they sometimes imply advocacy, even where none may exist. Furthermore, unfortunate slang variations of them (e.g., range con) can sound more criminal than professional. The Society for Range Management needs to lead in the identification and naming of the different categories of professionals involved with range management science. Then professionals like range management technicians will be able to clearly enunciate their professional identities with appropriate precision, and convey, in this case, the appropriate kind of conviction.

Adoption of the name range ecologist to replace range conservationist (the usual U. S. Office of Personnel Management title) would stretch the interpretation of the word ecology to the limits of elasticity. Concise descriptions of most range professionals' diverse activities include mostly the development of management science, or its implementation, i.e., management. Few of the activities of most range management scientists or range management technicians involve work within the traditional, mainstream context of ecology. Few scientists who recognize themselves as range ecologists would be likely to recognize management designs, plans, and their implementations as range ecology.

Changing the names of what are range management scientists and range management technicians to professional range ecologists would be another manifestation of range science's disciplinary retreat to the misperceived safe haven of ecology. Such a stretched, inaccurate name for technical professionals is unwarranted and unnecessary; the names range management scientist and range management technician are not nominally stretched, and are more descriptive of what most of these professionals actually do.

\section{Implications for the Society for Range Management}

Visualization of a range management science as described above, and as represented in Figure 5, has a number of other implications for the Society for Range Management, for its publications, and for its members. First, the name Society for Range Management is entirely compatible with this concept of range management science (as is International Society for Range Management, as discussed later in this paper). A major component of the Society's mission is encouraging informed, effective management of range. And while the word range carries significant historical, political baggage, the term is inherently and effectively broad in interpretation. Two of our challenges, ones we had better not fail in achieving, will be to foster and communicate this breadth in the interpretation of what we mean by range.

Recently, some university programs in range science or range management have attempted to strengthen their identities by changing the names of their departments or programs, often by adopting names including the word rangeland, e.g., rangeland ecology. As has been discussed previously, tying the core identity of range science to land, to rangeland, no matter how intuitively comforting that may seem, is narrowing and counterproductive. Range management science needs to imply and involve much more than simply the management of land. In fact, the name rangeland management, or the Society for Rangeland Management, would be less compatible with range management science, because the management science is synthetic; it involves many other elements than just land. We need to be counter-intuitive in this regard, and realize that even though land management may be a major goal, concepts make better building blocks for range management science than land does. If we can improve our identity and communication, and build an inclusive, integrative, creative management science, we have a better chance to overcome any current disadvantages of the word range, and make the word range work for us rather than against us. Then the Society for Range Management will remain a good name.

\section{Implications for the Journal of Range Management}

The name of the Society for Range Management's scientific journal, the Journal of Range Management, can be made more accurate, and more descriptive. If we adopt a simple semantic interpretation of range management, and define it as the actual, physical application, implementation, execution, etc, of range management science, then the Journal of Range Management is actually a journal of range management science. No actual range management (as defined above) is found there; it is all range management science.

Besides such technical accuracy, the name Journal of Range Management Science has other advantages. First, inclusion of the word science adds scientific credibility. Second, retention of the word management identifies it as a source of ideas to managers. Third, the compound phrase management science describes a diverse, inclusive, integrative science, and projects an image somehow broader than the image of range management. We 
should seriously consider renaming the Journal of Range Management the Journal of Range Management Science.

Adoption of an inclusive concept of range management science and an inclusive Journal of Range Management Science has other potential advantages. The current publishing environment in the specialized sciences, particular in ecology, has become highly competitive (Society for Range Management Task Force on the Journal of Range Management 2003). Because of the combined presence of older, more prestigious journals like Ecology, and well-established newer journals like The Journal of Arid Environments and Arid Land Research and Management, the Journal of Range Management will be unlikely to be the dominant publishing outlet in rangeland ecology or arid land ecology. The fact that the expansive editorial boards of these journals are peppered with researchers who might be considered important range ecologists further supports this observation. In the scholarly environment of ecology where publishing prestige is at a premium, we are unrealistic to expect that the Journal of Range Management can be the preferred outlet for most rangeland ecologists. Because of that expectation, we should not orient the Journal of Range Management predominantly as a journal of rangeland ecology.

Instead, we need a more inclusive editorial philosophy to attract as much highquality research relevant to range management science as we can. Range ecology, especially experimental research and conceptual research that involve the kind of integration, communication and synthesis involved in the mantle and core (Fig. 5) of range management science, should continue to be a major component of that research.

Orientation as a journal of an inclusive management science would place a Journal of Range Management Science in an environment of less direct competition with specialized journals. The greater diversity of possible contributions would welcome other scientists into the Society for Range Management, including international scientists, domestic scientists who are not in the traditional specialized sciences represented in Figure 1, but who could make significant contributions to range management science (Fig. 5).

Identifying the Journal as an inclusive Journal of Range Management Science would increase demands on the editorial board of the Journal. A greater number and diversity of associate editors will be needed, including ones oriented toward international research, diverse specialized sciences (Fig 5), and management science, including modeling. Because working with a management science philosophy that will encourage creativity and synthesis, the technical editor, with the assistance of the associate editors, will need to be diligent in the pursuit of objective research, and vigilant to avoid publishing both pseudo-scientific advocacy and management case studies that might be semidisguised as management science.

In an age of cooperative research, the lines are increasingly blurred between scientists and advocates, and such pseudoscience of dogma and demonstration are often the product of admirable cooperation. Cooperative organization of research can contribute to the development of management science, but some activities, such as simply gathering statistical data (Forrester 1961), or pseudo-scientific advocacy, contribute little of value to the management science. Science produced by research coalitions that may involve advocacy groups or individuals cooperating with poorly funded but nominally objective scientists will need increasingly careful editorial scrutiny.

\section{Internal or External Publishing}

Under a management science philosophy, the technical editor will need to give more attention to matters of mission, scope and quality however the Journal is published. If the Society for Range Management continues to publish its journal internally, the increased demands on the technical editor of a Journal of Range Management Science should be recognized by the Society with increased technical support and increased remuneration.

Any move to outside (joint) publishing would be likely to significantly change the role of the technical editor of the Journal. External publishing would reduce the editor's peripheral responsibilities in publishing, including matters of proofreading, formatting, etc., and redirect attention to defining the mission and scope of the Journal. Also, the technical editor would have more time to work with associate editors in improving the technical and literary quality of manuscripts.

\section{A New Journal?}

In the June, 2003 issue of Rangelands, the Society for Range Management Task Force on the Journal of Range Management (2003), based on an analysis of trends in published papers in the Journal, recommended exploration of a number of options, including consideration of a new journal of rangeland ecology. My analysis of that report (Scarnecchia 2003) in the August issue of Rangelands questioned the merit and interpretation of the Task Force's analysis, and contained an abridged version of the following analysis of why a second journal, one focused on rangeland ecology, seems at this time an inadvisable plan to pursue.

First, the new journal would be entering the highly competitive publishing environment of ecology described previously. In that environment, the new journal is not guaranteed to be an economic success.

Second, a new journal with an ecological emphasis would leave the current journal with strongly unbalanced content inconsistent with the diverse, inclusive management science philosophy espoused in this paper. The residual journal, with range ecology excised, is not guaranteed to be an economic success. If decreasing numbers of range ecology papers in the Journal of Range Management is a developing problem (Society for Range Management Task Force Report on the Journal of Range Management 2003), then their complete removal into a separate range ecology journal would be an acute problem.

Third, the current Journal of Range Management may be in need of an overhaul (in its identity, charges, subscription rates, delivery system, etc.), but notwithstanding some of the observations in the report of the Society for Range Management Task Force on the Journal of Range Management (2003), it is not "broken," at least not financially. In fact, financially, it is alive and reasonably well. Its profitability helps support other activities of the Society for Range Management. Dissecting a living organism seems unwise.

Fourth, although the Journal of Range Management, at least according to the interpretation of the report of the Society for Range Management Task Force on the Journal of Range Management (2003), has become more agricultural in its content, the lack of diversity in content created by a new journal of rangeland ecology would virtually force the original journal to publish entirely in the area of agriculture and grazing management, and thereby into becoming a journal of tacit advocacy. Any attempt to strengthen its content or finances by hybridizing the remaining journal with Rangelands would exacerbate this problem. In the current political environment, with Rangelands or without it, the remaining journal, with its unbalanced 
content, could not operate as a credible, objective, scientific journal if it were associated with advocacy, either explicit or tacit.

Fifth, the tacit advocacy would continue to undermine the reputation of the Society for Range Management as a source of diverse, objective, explicit range management science. In the process, it ironically would indirectly undermine the credibility of any new journal of rangeland ecology or rangeland science, because that new journal would be a sibling publication of a journal of tacit advocacy, with both being published by a society of tacit advocacy. In fact, scientists publishing in the new journal would likely be among the first to recognize and announce the unscientific character of the management journal. With its diverse membership, the Society for Range Management should pursue unstructured diversity in its scientific publishing in pursuit of scientific integrity and in its avoidance of advocacy.

Sixth, an ad hoc decision to add another journal would, unless the publication frequency of both journals were reduced significantly, overwhelm the current staff and strongly compel the Society into external publishing. Any decision regarding continuing internal publishing or initiating external publishing should be made as part of a proactive comprehensive plan, rather than as an ad hoc or reactive decision.

Seventh, and most fundamentally, creating a new Journal of Rangeland Ecology or Rangeland Science would perpetuate our failure to synthesize an inclusive, integrative range management science needed by the Society for Range Management, and by the institutions that contribute to it. Creation of the new journal would not address the broader problems of the Society and those institutions; it would not address the elements of identity and inclusiveness that the development of a single Journal of Range Management Science would address.

As part of a comprehensive publication plan, pursuit of a new, more specialized ecological journal as a companion journal to a Journal of Range Management Science remains a future possibility once the identity of range management science, and a Journal bearing that name, are more firmly established. But whatever the character or timing of future decisions, range ecology should continue to be a major contributor to range management science (Fig. 5), and to a Journal of Range Management Science.

The absence of local or regional experimental, agricultural research that involves little synthesis and has no apparent, gener- al value to range management science would effectively strengthen a Journal of Range Management Science. Relocation of papers describing such research into a joint publication involving other agricultural institutions would allow elimination of them from a Journal of Range Management Science, and leave Rangelands free to pursue more creative contributions.

\section{Implications of Range Management Science for Rangelands}

The potential for creativity and communication through Rangelands should be significantly enhanced by a publishing philosophy based on range management science, and by a Journal of Range Management Science, because the inclusiveness of a management science philosophy should give Rangelands a greater diversity of contributions to publish. Rangelands has an essential role within the expanded concept of communication that this paper implores, including communication among range management scientists, range management technicians, and readers interested in the activities surrounding rangelands. The increased inclusiveness of the management science philosophy should invite contributions from non-traditional authors, from non-traditional disciplines, and allow upgrading of the technical and literary quality of Rangelands.

As a non-technical or semi-technical publication of the Society for Range Management, Rangelands should not indulge in the unbalanced pro-grazing advocacy of the magazine Range, or any overstated anti-grazing or pro-grazing advocacy of politically extreme publications. Rangelands, like a Journal of Range Management Science, should be characterized by unstructured diversity in its pursuit and communication of meritorious information, and should be vigilant in avoiding scientifically unjustifiable positions of advocacy.

\section{Implications of Range Management Science for Programs at Universities}

The American universities are likely to be hugely important in the future of range management science as an identifiable science, and in the perpetuation of the Society for Range Management, for at least the following reasons.

First, research scientists at universities, including the land-grant universities, have historically been important contributors to innovation in range management science. The interdisciplinary environments of uni- versities both employ and educate personnel for the kind of interdisciplinary working groups that can pursue the integrative designs in the core of range management science.

Second, the universities have historically been recognized as the institutions most likely to conduct objective research. Notwithstanding recent and ongoing deterioration in independent, hard money funding for research at these institutions, they still promise to be important sources of objective research. The Society for Range Management and a Journal of Range Management Science must have and promote such objective research if they are to pursue objective science rather than advocacy, as has been recommended by Fuhlendorf et al. (1999).

Third, universities are the rearing grounds for undergraduate and graduate students who will become the next generations of range management scientists and range management technicians. Lack of students will eventually translate into a smaller quantity and a lower quality of these professionals. The membership of students and other young professionals is essential for a healthy demographic structure of membership in the Society for Range Management. The current demographics of the Society are already skewed in favor of older members. The universities are the source of young professionals, who are the new and typically long-term members of the Society.

Over the past 20 years, the land-grant universities have gradually become less dedicated to the traditionally broad landgrant mission, and have come to operate more like businesses with self interest, providing selective, high value (to the institution) products, in both research and education. Management generally has proven to be less lucrative to these institutions than has intensive, technological science. An arguably shortsighted, specious ethic has developed that we can engineer our way out of problems more effectively than we can manage them, fueled partly no doubt by the historical observation that people have often proven less than proficient at management. At these universities, traditional range management, with its history of poor extramural financial support, and limited student interest, in a phrase, hasn't cut it. As a result, range management programs, especially some of the stronger programs, have been scaled back, and range management programs at the major universities, including the landgrant universities, are, in many senses, weaker than they have been in decades. 
Given the current and increasing predominance of financial considerations in determining the viability of programs at land-grant universities, the future prospects for traditional range management programs at these institutions do not seem bright. One possibility for contributing some improvement of these prospects is to adopt the inclusive concept of range management described in this paper. Adoption of this approach has several advantages.

First, by becoming a true, integrative management science, range management science can become the program of choice for undergraduate and graduate students with diverse interests in integrated natural resource management. In a disciplinary landscape of well-established environmental and production sciences, a strong, identifiable discipline does not currently exist that is directed at broad considerations of active management of human, environmental, and physical resources. Range management science can fill this disciplinary vacuum at the region's land-grant universities, especially in a region of predominantly arid rangeland like the western United States. The students, at least, are there. To offer coherent programs, faculty members at these institutions will, at the most philosophical level, need to find common identity within the core of range management science of Figure 5, not only the traditional, comfortable, discrete identities within the mantle.

Second, compared with the narrow disciplinary implications of the pedestrian image of traditional range management, the adoption of range management science will provide increased scientific credibility and technical identification at these institutions. The name provides a claim of relevance to both science and management.

Third, the philosophical breadth of a range management science program still allows each institution the philosophical space to design a program to accommodate the regional needs or unique characteristics of its students. The emphases desired within range management science programs by students can be radically different at, for example, the University of Wyoming than at Humboldt State University. Range management science provides situational flexibility while maintaining disciplinary integrity. Also, its philosophical breadth offers the possibility of more potential homes within the administrative units of academic institutions,

Fourth, notwithstanding the current trends favoring bioengineering over management of agricultural and ecological systems, and favoring unmanaged preservation over managed production and managed conservation, the longer-term future trends are unclear. Increasing human population and increasing demands on natural resources will continue to increase interest in multiple efficiencies. The inherent integrated diversity of range management science should be especially advantageous in the design, development and implementation of management systems to address multiple efficiencies rather than traditional, single-product production. Those same increasing human demands, and the desire to formulate environmentally friendly solutions to ecological problems such as weed invasions, catastrophic fires, etc. should inevitably favor an increased role for active, integrated management, on lands held for ecological preservation.

Most of the natural resource disciplines arose to control damage from the intensive activities of technical specialists of different kinds; these disciplines arose to clean up the created problems of private or public engineers of one kind or another. Looking ahead, the proliferation of bioengineers and other technical scientists of all kinds, and the sometimes unsystematic, tactical tinkering of their work, when combined with an increasing interest in preserving natural landscapes in the presence of such human engineering, portend plenty of opportunities in the future to design and develop integrated solutions to manmade problems. Range management science, as envisioned in this paper, should be well positioned to address these likely future opportunities with integrative management solutions, whether the current pro-technology trend continues, in the event of a strengthened anti-technology social countertrend, or in the likely case that both trends proceed simultaneously. In any case, the increasingly complex objectives of modern activities, and increasing interest in interdisciplinary, cooperative research promise scholarly and financial opportunities for a range management science designed to integrate specialized sciences, address multiple objectives, achieve multiple efficiencies, and communicate accurate, useful information.

The curricula at the universities interested in range management science will need to be individually, significantly re-oriented to strengthen skills in, among other areas, systems science, art and design, and communication. In graduate programs, increased attention will need to be directed at interdisciplinary projects. Considerations and pursuit of art and design of integrative abstractions, more than just multi-discipli- nary science, will be needed to elevate graduate projects above case studies, and provide the synthesis to raise studies to the level of management science. Details of other likely changes are beyond the scope of this paper, but the Society for Range Management, through its committees on education and accreditation, can assist in the design of these educational curricula in range management science.

\section{International Dimensions of Range Management Science}

Many of the contributions to range management science from outside of North America, including the contributions from development projects in developing countries, have involved more integrated management science than specialized, basic or applied science. In fact, professionals involved in international development projects in developing countries, in their efforts to design creative, adaptive, or coordinated management plans rather than specialized, technical research, have been, in many cases, unequivocal leaders in developing some of the kinds of syntheses that are at the core of range management science. Some of this work has been conducted within development concepts such as farming systems, agroforestry, etc. Unfortunately, preoccupation with specialized, experimental science has marginalized many of the synthetic, scientific contributions of many of these scientists and technicians. In some cases, a combination of scholarly elitism and a narrow concept of research have shunted such efforts toward broad-minded but respected technical publications, and away from experimentally-oriented publications, including, to some degree, the Journal of Range Management.

The identity and development of range management science have not benefited from this parochialism. No doubt, membership in the Society for Range Management has suffered.

For reasons of both science and business, the Society for Range Management needs enhanced pursuit of the international dimensions of range management science. An inclusive philosophy of range management science, a Society for Range Management that views diversity synergistically, and a Journal of Range Management Science that is broad in concept, significantly, and inherently, increase the potential for international activities in the Society for Range Management.

Recently, M. M. Kothmann (personal communication) related that the Board of Directors of the Society for Range 
Management had (again) discussed renaming the Society for Range Management the International Society for Range Management. Such action would have significant potential value, insignificant disadvantages, and little cost (at least beyond the expansion of the editorial board of the Journal that was discussed previously). $A$ Journal of Range Management Science, with a sub-heading of A Journal of the International Society for Range Management would clearly show that the Society is interested in attracting international members, and their scientific contributions.

\section{Concerning the Next Incarnation of the Range Glossary Committee}

Developing range management science beyond philosophical generalities will require increased efforts in the area of concept design. Many of our concepts used in range management over the years have been developed for ad hoc applications in management, and are inadequately designed for optimal use in a management science (For an example, see Scarnecchia (2004a). Because concepts of many kinds are the functional tools of a management science, development of an improved management science will require greatly increased efforts in the synthesis of concepts. An earlier paper (Scarnecchia 1996) examined some basic considerations, including abstracting and confounding, that are involved in the design of concepts for range management science. That same paper explained the idea of a conceptual hierarchy, from the simplest of a group of related concepts to the most complex.

We have never had a comprehensive examination of the concepts used in range management, and an evaluation of their general utility in range management science. Because definition requires conceptuality (Fuller 1975), and because synthetic concepts of varying complexities are at the core of range management science, the next Range Glossary Committee should consider focusing more on developing a glossary of concepts rather than a glossary of definitions. A glossary of concepts should differ from the past editions of the Glossary of Terms Used in Range Management in several ways.

First, significantly more care should be given to citing the sources of the concepts and corresponding definitions used. Such care is more in line with the standard protocol of scientific citation, and rigorous citation also provides important supporting documentation to the concepts. Such documentation would stretch the inherently limited format of a glossary.
Second, the definitions should be annotated with supporting analyses and descriptions. The descriptive and analytical annotations should include such matters as the origin (s) of the concept, some characterization of the concept, the kind of communication function the concept is designed to accomplish in range management science, relevant past applications, and description of at least some of its appropriate applications. Variations within and outside of range management science should be noted. The supporting analyses and evaluations recommended here will require a publication of significantly greater length, detail, and organization than the previous booklets.

Third, the design of the entire book of concepts should ideally be based on some generalized classification of conceptspossibly a hierarchical classificationone arranged according to the relative complexity or the abstraction or interactivity of each concept within range management science. Achievement of this objective will require a significant effort directed at synthesis and design before and during the development of the book of concepts. The individuals on the committee to undertake this effort should have diverse backgrounds and experiences, but because conceptuality inherently involves abstraction, the individuals should all have interest and skill in abstract thinking.

A book of concepts as described here would be a significant contribution toward establishing a stronger identity for range management science. It would be a logical effort for the Society for Range Management, because the Society would be the principal institutional force with a stake in the establishment and furtherance of range management science.

\section{Empowering Diversity}

No theme at the recent Annual Meeting of the Society for Range Management was more forceful and pervasive than diversity. The nametags for the meeting read Rangelands: Diversity through Time. I heard several speakers refer to this theme in referring to the importance of biodiversity on rangelands. The theme was admirable, but everything I saw at that meeting reminded me that I would have omitted the colon in the title by omitting the first word.

From its earliest conception as a management art, to its many manifestations as comprehensive management, to its conception here as range management science, the science has, intentionally, unknowingly, or inevitably, sought identi- ty in inclusive, integrative solutions to questions involving diverse elements. The diversity involves more than just biodiversity on rangeland; it involves diversity of contributing sciences, viewpoints, cultures, people, products, processes, values, objectives and efficiencies.

As a philosophical concept, range management science should bring increased diversity of scientists and ideas to the Society for Range Management. In the process, the already ongoing increase in social diversity in the Society will be naturally fostered in an unforced, evolutionary environment. Such unforced social diversity will assist in maintenance of philosophical unity and professional integrity within the Society.

\section{The Future and Range Management Science}

The challenges facing the Society for Range Management should be addressed comprehensively. In the absence of significant, substantive changes, current trends are not encouraging. Continued inaction seems risky, and unwise.

We need to be counter-intuitive here, and resist the defensive tendencies to indulge in expedient political or pseudoscientific advocacy, or to withdraw scientifically to specialized sub-sciences like range ecology or range animal science. Instead, we should pursue a diverse, inclusive, dynamic concept of range management science because it is a sound strategic course-a course that has scientific space, creative opportunity, and professional integrity. While success is not guaranteed, the inclusiveness of this concept of range management science increases the potential for success, and reduces the risk of extinction due to specialization without a definable specialty.

The concept of range management science described here is designed to accommodate virtually everyone within the Society for Range Management, and to attract others to the Society. It is more empirically interpretive than radically creative; it conceptualizes and accommodates the naturally evolving trends in range science and in the Society for Range Management's professionals. Designed to interpret what is happening to range science and range management in a complex, natural, competitive environment, range management science as a concept owes more to the subtleties of ecological influence than the force of agricultural imposition (Scarnecchia 2003). And precisely 
because it is not forced, because it is derived by listening to the cultural landscape, it is a low risk proposition.

In a sense, the design of this paper, involving diverse elements, integrative analysis, and multiple objectives, is an example of the kind of synthesis that is at the core of range management science; this paper exemplifies what it espouses. The vision it presents is an harmonious one; it gives range management science a strong, identifiable, marketable identity. That vision involves and promotes precise language, transparent actions, and effective communication. Range management science is designed to take full advantage of the diversity of content that has fragmented range science as a technical science, and the diversity of perspectives that has clouded range management as an applied profession. The concept of range management science empowers the diversity of its contributing sciences and of its working professionals, and establishes a philosophical environment of technical and social unity where the scientific, institutional, informational, and professional synergies we need can flourish.

\section{Literature Cited}

Eiseley, L. 1959. The immense journey. Charles Scribner's Sons, New York, N. Y.

Forrester, J. W. 1961. Industrial dynamics. The M. I. T. Press, Cambridge, Mass.

Fuhlendorf, S. D., C. S. Boyd, and D. M. Engle. 1999. SRM philosophy: Science or advocacy? Rangelands. 21(1):20-23.

Fuller, R. B. 1975. Synergetics. Macmillan and Co., New York, N.Y.

Gass, S. I. and C. M. Harris, eds. 1996. Encyclopedia of operations research and management science. Kluwer Academic Publishers, Boston, Mass. 753 p.

Holechek, J. L., R. D. Pieper, and C. H. Herbel. 2004. Range management, principles and practices, $5^{\text {th }}$ edition. Pearson Prentice Hall, Upper Saddle River, N. J.

Provenza, F. D. 1991. Viewpoint: Range management and range science are complementary but distinct endeavors. J. Range Manage. 44:181-183.

Scarnecchia, D. L. 1995a. Viewpoint: The rangeland condition concept and range science's search for identity: a systems viewpoint. J. Range Manage. 48:181-186.

Scarnecchia, D. L. 1995b. Book review. Rangeland ecology and management. J. Range Manage. 48:478-479.

Scarnecchia, D. L. 1996. Concept design in range management science. J. Range Manage. 49:421-424.

Scarnecchia, D. L. 1999. Viewpoint: The range utilization concept, allocation arrays, and range management science. J. Range Manage. $52: 157-160$
Scarnecchia, D. L. 2003. Improving the Journal of Range Management: Some management science philosophy and ecological observations. Rangelands. 25(4):43-46.

Scarnecchia, D. L. 2004a. Viewpoint: Entropy, concept design, and animal-unit equivalence in range management science. J. Range Manage. In press.

Scarnecchia D. L. 2004b. Viewpoint: Synthesis, range management science, the Journal of Range Management. In press.

Scarnecchia, D. L. 2004c. Viewpoint: Stochastic research, management implications, and the Journal of Range Management. In press.

Scarnecchia, D. L. 2004d. Viewpoint: Writing book reviews for the Journal of Range Management and Rangelands. In review.

Scarnecchia, D. L., and C. T. Gaskins. 1987. Modeling animal-unit equivalents for beef cattle. Agr. Syst. 23:19-26.

Society for Range Management Task Force Report on the Journal of Range Management. 2003. An analysis of the Journal of Range Management: Report of the SRM Task Force. Rangelands. 25(3):13-22.

Stoddart, L. A. and A. D. Smith. 1943. Range management. McGraw-Hill, New York, N. Y.

Stoddart, L. A. and A. D. Smith. 1955. Range management, $2^{\text {nd }}$ edition. McGraw-Hill, New York, N. Y.

Stoddart, L. A., A. D. Smith, and T. W. Box. 1975. Range management, $3^{\text {rd }}$ edition. McGrawHill, N. Y.

Vavra, M. 2003. What the heck is range management? The Trail Boss News. Soc. for Range Manage, Denver, Colo. June:1-2. 